\title{
Letramentos escolares: coletâneas de textos nos livros didáticos de língua portuguesa
}

\author{
Roxane Helena Rodrigues Rojo*
}

\section{Resumo}

O presente artigo discute os letramentos característicos da contemporaneidade, para, em seguida, voltar-se para os letramentos escolares, com base no perfil das coletâneas de textos do livro didático de Língua Portuguesa (LDP) ${ }^{1}$ que circulou nas redes públicas brasileiras de Ensino Fundamental (1 a a $4^{\underline{a}}$ série), de 2004 a 2009. A análise dessas coletâneas, em termos de gêneros representados e de suas esferas de circulação, discute os letramentos escolares possíveis a partir desses textos. Os resultados mostram que o LDP ainda está longe de incorporar os letramentos requeridos na contemporaneidade.

Palavras-chave: Livros didáticos. Alfabetização. Leitura. Escrita.

* Professora Doutora do Departamento de Linguística Aplicada do IEL/UNICAMP/DLA/ IEL/UNICAMP. 


\section{Introdução}

As abordagens mais recentes dos letramentos ${ }^{2}$, em especial aquelas ligadas aos Novos Estudos do Letramento (NLS), têm apontado para a heterogeneidade das práticas sociais de leitura, escrita e uso da língua/ linguagem em geral em sociedades letradas e têm insistido no caráter sociocultural e situado das práticas de letramento (HEATH, 1983; STREET, 1984, 1995, 2003; BARTON, 1994; BARTON; HAMILTON, 1998; GEE, 1996; PRINSLOO; BREIER, 1996; dentre outros). Esta posição, como nota Street (2003, p. 77),

implica o reconhecimento dos múltiplos letramentos, que variam no tempo e no espaço, mas que são também contestados nas relaçóes de poder. Assim, os NLS não pressupóem coisa alguma como garantida em relação aos letramentos e às práticas sociais com que se associam, problematizando aquilo que conta como letramento em qualquer tempoespaço e interrogando-se sobre "quais letramentos" são dominantes e quais são marginalizados ou de resistência ${ }^{3}$.

Voltando-se este artigo para o perfil do livro didático de Língua Portuguesa (doravante, LDP) que circula nas redes públicas de Ensino Fundamental ( $1^{\mathrm{a}}$ a $4^{\mathrm{a}}$ série), insere-se, é claro, no campo de investigação dos letramentos "dominantes". Hamilton (2002, p. 4) chama os letramentos dominantes de "institucionalizados" e os distingue dos letramentos locais "vernaculares" (ou autogerados). Entretanto, não os vê como categorias independentes ou radicalmente separadas, mas interligadas. Para a autora, os letramentos dominantes estáo associados a organizaçóes formais tais como a escola, as igrejas, o local de trabalho, o sistema legal, o comércio, a burocracia. Caracteriza-os como "parte dos discursos especializados incluídos em comunidades de práticas, padronizados e definidos em termos dos propósitos formais da instituição, ao invés de pelos propósitos múltiplos e integrados dos cidadãos e de suas comunidades." (HAMILTON, 2002, p. 4). Os letramentos dominantes envolvem agentes (professores, autores de LD, especialistas) que, em relação ao conhecimento, são valorizados legal e culturalmente, são poderosos na proporção do poder da sua instituição 
de origem. Já os chamados letramentos "vernaculares" não são regulados, controlados ou sistematizados por instituições ou organizaçóes sociais, mas têm sua origem na vida cotidiana, nas culturas locais. Como tal, frequentemente são desvalorizados ou desprezados pela cultura oficial e são práticas de resistência ou táticas, no sentido de Certeau (1994).

Os Novos Estudos do Letramento têm se voltado em especial para os letramentos locais ou vernaculares, de maneira a dar conta da heretogeneidade das práticas não valorizadas e, portanto, pouco investigadas. No entanto, cabe também uma revisão dos letramentos dominantes, em especial dos letramentos escolares, na contemporaneidade, por diversas razóes.

Em primeiro lugar, por causa de como se apresenta o mundo contemporâneo. Podemos dizer que, efeito da globalizaçấo, o mundo mudou muito nas últimas duas décadas. Em termos de exigências de novos letramentos, é especialmente importante destacar as mudanças relativas aos meios de comunicaçáo e à circulaçáo da informaçáo. $\mathrm{O}$ surgimento e a ampliaçấo contínua de acesso às tecnologias digitais da comunicaçáo e informação (computadores pessoais, mas também celulares, tocadores de mp3, TVs digitais, entre outras) implicaram pelo menos três mudanças que ganham importância na reflexão sobre os letramentos socialmente requeridos:

- a intensificação vertiginosa e a diversificação da circulação da informação nos meios de comunicação analógicos e digitais, que, por isso mesmo, distanciam-se hoje dos meios impressos, muito mais morosos e seletivos, implicando, segundo alguns autores (CHARTIER, 1998; BEAUDOUIN, 2002), mudanças significativas nas maneiras de ler, de produzir e de fazer circular textos nas sociedades;

- a diminuiçăo das distâncias espaciais - tanto em termos geográficos, por efeito dos transportes rápidos, como em termos culturais e informacionais, por efeito da mídia digital, desenraizando as populaçôes e desconstruindo identidades; e a diminuição das distâncias temporais ou a contraçấo do tempo, determinadas pela velocidade sem precedentes, da quase instantaneidade, dos transportes, da informação, dos produtos culturais das mídias, características que também colaboram para mudanças nas práticas de letramentos; 
- a multissemiose que as possibilidades multimidiáticas e hipermidiáticas do texto eletrônico trazem para o ato de leitura: já não basta mais a leitura do texto verbal escrito - é preciso colocálo em relação com um conjunto de signos de outras modalidades de linguagem (imagem estática, imagem em movimento, som, fala) que o cercam, ou intercalam ou impregnam; esses textos multissemióticos extrapolaram os limites dos ambientes digitais e invadiram também os impressos (jornais, revistas, LDs).

Por outro lado, a escola - em especial a pública - também mudou bastante nos últimos 50 anos no Brasil, mas não na mesma direção. Buscouse - e atingiu-se, na década de 90 - a universalização do acesso à educação pública no Ensino Fundamental, e hoje se busca a mesma ampliação e universalização de acesso no Ensino Médio. Claro está, acesso não quer dizer permanência e nem qualidade de ensino. Ainda assim, a ampliação de acesso tem impactos visíveis nos letramentos escolares: o ingresso de alunado e de professorado das classes populares nas escolas públicas trouxe para os intramuros escolares letramentos locais ou vernaculares antes desconhecidos e ainda hoje ignorados. Isso cria uma situação de conflito entre práticas letradas valorizadas e não valorizadas, como apontam os trabalhos de Heath (1983) e Kleiman (1995; 1998), por exemplo, que beiram a situação diglóssica.

Hamilton (2002, p. 8) vai apontar para o fato de que muitos dos letramentos que são influentes e valorizados na vida cotidiana das pessoas e que têm ampla circulação são também ignorados e desvalorizados pelas instituiçóes educacionais: "não contam como letramento 'verdadeiro'.” Da mesma maneira, as redes sociais e informais que sustentam essas práticas letradas permanecem desconhecidas e apagadas nas escolas.

Esses movimentos fazem ver a escola de hoje como um universo de letramentos múltiplos e muito diferenciados, cotidianos e institucionais, valorizados e não valorizados, locais, globais e universais, vernaculares e autônomos, sempre em contato e em conflito, sendo alguns ignorados e apagados e outros constantemente enfatizados.

Por fim, nessas circunstâncias, o que significa trabalhar a leitura e a escrita para o mundo contemporâneo? Ou, como diz Hamilton (2002), como esboçar políticas de letramento "ao longo da vida" que realmente 
sustentem e desenvolvam os recursos, processos e metas que existem e são requeridos na vida cidadã?

Um dos objetivos principais da escola é justamente possibilitar que seus alunos possam participar das várias práticas sociais que se utilizam da leitura e da escrita (letramentos) na vida da cidade, de maneira ética, crítica e democrática. Para fazê-lo, é preciso que a educação linguística leve em conta hoje:

- os multiletramentos ou letramentos múltiplos, também de maneira ética e democrática, deixando de ignorar ou apagar os letramentos das culturas locais de seus agentes (professores, alunos, comunidade escolar) e colocando-os em contato com os letramentos valorizados, universais e institucionais; como diria Santos (2005), assumindo seu papel cosmopolita ${ }^{4}$;

- os letramentos multissemióticos exigidos pelos textos contemporâneos, ampliando a noção de letramento para o campo da imagem, da música, das outras semioses que não somente a escrita, como já prenunciava, por exemplo, a noção de "numeramento" cunhada no campo da Matemática; os conhecimentos de outros meios semióticos estão ficando cada vez mais necessários no uso da linguagem, tendo em vista os avanços tecnológicos: as cores, as imagens, os sons, o design etc., que estão disponíveis na tela do computador e em muitos materiais impressos, os quais têm transformado o letramento tradicional (da letra/livro) em um tipo de letramento insuficiente para dar conta dos letramentos necessários para agir na vida contemporânea (MOITA-LOPES; ROJO, 2004);

- os letramentos críticos e protagonistas requeridos para o trato ético dos discursos em uma sociedade saturada de textos e que não pode lidar com eles de maneira instantânea, amorfa e alienada; como afirmam Moita-Lopes e Rojo (2004, p. 37-38, ênfase adicionada), é preciso levar em conta

o fato de que a linguagem não ocorre em um vácuo social e que, portanto, textos orais e escritos não têm sentido em si mesmos, mas interlocutores (escritores e leitores, por exemplo) situados no mundo social 
com seus valores, projetos políticos, histórias e desejos constroem seus significados para agir na vida social. Os significados são contextualizados. Essa compreensão é extremamente importante no mundo altamente semiotizado da globalizaçáo, uma vez que possibilita situar os discursos a que somos expostos e recuperar sua situacionalidade social ou seu contexto de produçáa e interpretação: quem escreveu, com que propósito, onde foi publicado, quando, quem era o interlocutor projetado etc. Tal teorização tem uma implicação prática, porque possibilita trabalhar em sala de aula com uma visão de linguagem que fornece artifícios para os alunos aprenderem, na prática escolar, a fazer escolhas éticas entre os discursos em que circulam. Isso possibilita aprender a problematizar o discurso hegemônico da globalização e os significados antiéticos que desrespeitem a diferença.

Essas múltiplas exigências que o mundo contemporâneo coloca para a escola, portanto, vão multiplicar enormemente as práticas e textos que nela devem circular e ser abordadas(os). O letramento escolar, tal como o conhecemos, voltado principalmente para as práticas de leitura e escrita de textos em gêneros escolares (anotaçóes, resumos, resenhas, ensaios, dissertações, descrições, narrações e relatos, exercícios, instruções, questionários, dentre outros) e para alguns poucos gêneros escolarizados advindos de outras esferas (literária, jornalística, publicitária) não será suficiente para atingir as três metas enunciadas acima. Será necessário ampliar e democratizar tanto as práticas e eventos de letramentos que têm lugar na escola como o universo de textos que nela circula. É na esteira desta necessidade que o presente artigo se justifica.

\section{Letramentos e o LDP}

As pesquisas sobre letramentos no Brasil têm apontado um lugar de destaque para a escola e o livro escolar na constituição e distribuição dos letramentos. O Indicador Nacional de Alfabetismo Funcional (INAF) ${ }^{5}$ aponta a leitura de livros religiosos e escolares como práticas bastante difundidas de letramento no Brasil. 
Trabalhando os resultados do INAF de maneira mais focada, Abreu (2003) nos mostra que parece haver uma relação direta entre escolarização e gosto pela leitura, por exemplo. Os entrevistados, questionados a respeito de pessoas que influenciaram seu gosto pela leitura, indicam, em primeiro lugar, o(a) professor(a) (37\%), a mãe (36\%) e o pai (24\%), o que aponta para a (esperada) importância da família e da escola na (re)produção das práticas letradas. A investigação sobre a presença de impressos na casa das pessoas também surpreendeu, pois, apesar das desigualdades sociais, 98\% dos entrevistados têm materiais impressos em casa. Claro está, a desigualdade social está expressa nas quantidades: $24 \%$ da população investigada têm até quatro tipos de materiais; $27 \%$ têm até 7 e $49 \%$ têm mais de 8 tipos; nas classes $\mathrm{A} / \mathrm{B}, 93 \%$ têm mais de oito tipos de materiais impressos. No entanto, $34 \%$ dos analfabetos têm dicionário em casa.

Esses dados apontam para a importância das políticas públicas do livro escolar (em especial, o PNLD) na (re)produção dos letramentos. Esses dicionários, possivelmente, foram distribuídos pelo Programa Nacional do Livro Didático (PNLD) aos filhos ou netos desses analfabetos.

Quando examinamos a posse de livros, a desigualdade social e importância da escola ficam reafirmadas. Somente $15 \%$ da população investigada possuem de 50 a 100 livros ou mais, mas $78 \%$ da população possuem entre 10 e 50 livros. Desses detentores de livros, 50\% compram, 8\% recorrem a bibliotecas e $4 \%$ à escola, resultado que aponta para a ineficácia das bibliotecas ${ }^{6}$ e, novamente, para o papel do livro escolar.

Quando nos interessamos por quais livros são esses que estão nas casas das pessoas, a importância das políticas públicas de distribuição do livro escolar salta aos olhos: da amostra total, 65\% declaram ter dicionários; $59 \%$, livros didáticos (com destaque para cartilhas e livros de alfabetização); $58 \%$, livros infantis e $35 \%$, enciclopédias. Se considerarmos a literatura infantojuvenil brasileira como um mercado paraescolar, as três primeiras categorias (dicionários, LDs e livros infantis ${ }^{7}$ ) são objeto de distribuição governamental por meio da escola.

Finalmente, quando nos indagamos sobre os impressos mais lidos, Abreu (2003) nos mostra que a leitura religiosa e a escolar "estão em alta" e que a leitura literária (valorizada ou não) é privilégio das classes superiores: 46\% da população investigada, concentrados nas classes C/D e nas Regióes Norte e Centro-Oeste, declaram ler a Bíblia, livros sagrados ou religiosos; 
$30 \%$, concentrados nas classes $\mathrm{A} / \mathrm{B}$ e na população jovem, declaram ler romances, livros de aventura, policial ou ficção e $20 \%$ da população jovem dos segmentos A/B, poesia.

Se estendemos nosso interesse a outras práticas culturais letradas, que exigirão letramentos multissemióticos, veremos que $81 \%$ da população entrevistada assistem regularmente à TV e que $78 \%$ ouvem rádio, mas que $83 \%$ nunca foram ao teatro, $78 \%$ nunca foram a museus, $68 \%$ nunca foram ao cinema, 59\% nunca alugam filmes, 50\% nunca vâo a shows e $45 \%$ nunca foram à exposição ou feira.

Ou seja, embora as pessoas possuam livros escolares, as igrejas formam mais leitores que a escola, a TV e o rádio dominam a comunicação e a informação e a escola só dá acesso ao letramento literário aos alunos das classes privilegiadas. Também o acesso a outros espaços da cultura valorizada (teatro, museu, cinema, show, exposição etc.) é restrito a essas classes.

Em todo caso, os dados apontam para a importância do livro escolar nos letramentos e na distribuição do livro no Brasil. Como afirma Batista (2003, p. 30), num país como o Brasil, de parcimoniosa distribuição do livro,

o manual didático é um dos poucos gêneros de impresso com base nos quais parcelas expressivas da população brasileira realizam uma primeira - e muitas vezes única - inserção na cultura escrita. É, também, um dos poucos materiais didáticos presentes cotidianamente na sala de aula, constituindo o conjunto possibilidades com base nas quais a escola seleciona seus saberes, organiza-os, aborda-os.

Para boa parte da população brasileira com acesso à escola, é a partir das coletâneas de textos dos LD que os eventos de letramento em diferentes esferas de comunicação poderão ter lugar.

\section{As coletâneas de textos dos LDP e os letramentos}

Bunzen (2005) e Bunzen e Rojo (2005) trabalham com a hipótese de que a origem, na década de 70 do século passado, da configuração atual do gênero LDP ou manual didático de Língua Portuguesa, tal qual o conhecemos hoje, 
advém de uma confluência, para o LDP, de três outros gêneros: a antologia, a gramática e a aula. [...] A gramática e a coletânea de textos (antigamente impressa em antologias e seletas) são fundidas com e permeadas por um conjunto de instrumentos de normalização das atividades (observar, ler e responder questionários etc.) e com as explicaçóes didáticas, agora não mais realizadas pelo professor, mas pelos novos autores de livro didático (BUNZEN; ROJO, 2005, p. 79).

Neste sentido, a coletânea de textos que integra os LDP herda as funções normalizadoras, reguladoras e curriculares das antigas antologias e pode ser tomada como indicadora das intençóes de ensino e, decorrentemente, dos letramentos possíveis de serem apropriados pelos alunos, a partir das coletâneas. Descrever essas coletâneas e os letramentos que podem prever é o objetivo deste artigo.

É claro que não se pode pensar os eventos concretos de letramento a partir do LDP sem se levar em conta as práticas de sala de aula dos professores e as instruçóes e questóes de trabalho sobre os textos propostos pelos autores de LDP. No entanto, a própria circunscrição e seleção dos textos feitas por autores e editores já delimita um conjunto de possibilidades de leituras e de práticas de letramento possíveis e outro conjunto que não o é.

$\mathrm{Na}$ introdução deste texto, falamos dos multiletramentos ou letramentos múltiplos necessários hoje à vida cidadã e os descrevemos como compostos tanto de letramentos valorizados pela escola e tidos como universais, como pelos letramentos locais ou vernaculares que povoam a vida cotidiana da comunidade escolar, em geral, pouco ou não valorizados institucionalmente. Logo, os letramentos são muito variados e diversificados e escolhas se imporão ao autor/editor do LDP, no universo das práticas, de gêneros e textos que estão envolvidos em práticas diversas de culturas também diversas.

Neste artigo, tomaremos as noçóes de cultura local e global ${ }^{8}$; de esferas de letramento (RIBEIRO, 2003) e de esferas de atividade e de circulação de discursos (BAKHTIN, 2003) como organizadoras desta ampla diversidade de textos, gêneros e práticas de letramento. Ribeiro (2003, p. 21), ao explicar 
a organização do questionário do INAF/2001, define "esferas de letramento" como "esferas de vivência cotidiana em que práticas de leitura e escrita podem estar presentes" e as elenca como "doméstica, do trabalho, do lazer, da participação cidadá, da educação e da religião”. Nota-se a proximidade da noção com o conceito de esferas de atividade e de circulação de discursos do Círculo de Bakhtin (1992, 2003), que tem sido aproximada e mesmo traduzida como "campo". Bakhtin e Volochinov (1992, p. 33) aproximam a noção de esfera de comunicação social ou de criação ideológica da materialidade semiótica e dos gêneros:

No domínio dos signos, isto é, na esfera ideológica, existem diferenças profundas, pois este domínio é, ao mesmo tempo, o da representação, do símbolo religioso, da fórmula científica e da forma jurídica, etc. Cada campo de criatividade ideológica tem seu próprio modo de orientação para a realidade e refrata a realidade à sua própria maneira. Cada campo dispóe de sua própria função no conjunto da vida social.

Grillo (2006) aproxima a noção bakhtiniana de "esfera” à noção de "campo" de Bourdieu, afirmando que, em ambos os casos, o conceito reflete e refrata (traduz) as condiçóes, sobretudo socioeconômicas, da atividade humana: "um espaço social capaz de refratar, traduzir ou transformar as demandas externas, sobretudo da base sócio-econômica comum.” Para Bakhtin (2003), as esferas podem estar mais ligadas à infraestrutura social, à ideologia do cotidiano, como as esferas cotidianas íntima, familiar, do trabalho - neste caso, povoadas sobretudo de gêneros primários -, ou à superestrutura social e às ideologias oficiais ou cristalizadas - caso em que farão circular textos em gêneros secundários -, como as esferas jornalística, escolar, científica, artística, literária, publicitária, dentre outras.

Neste sentido, o conceito bakhtiniano de "esferas de circulação de discursos" pode dar mais especificidade e detalhamento à noção de "esferas de letramento" esboçada por Ribeiro (2003, p. 15) e, por esta via, à de letramentos múltiplos ou multiletramentos. Por exemplo, podemos pensar que, no que Ribeiro denomina de "esfera da participação cidadã”, verificam-se práticas letradas que se exercem sobre discursos/textos em gêneros pertinentes a várias esferas de circulação discursiva, como a política, jurídica, burocrática, jornalística etc. 
É de se esperar, na alta modernidade, que as coletâneas dos LDP não se atenham mais exclusivamente a textos da esfera literária e que possibilitem práticas de letramento de esferas diversificadas de circulação dos discursos, por meio da leitura de textos em gêneros também variados. Esta expectativa é que suporta as duas questóes de pesquisa a que buscamos responder neste artigo:

- Quais gêneros e esferas são privilegiados na escolha autoral/editorial para compor as coletâneas de textos dos $\operatorname{LDP}\left(1^{\mathrm{a}}\right.$ a $4^{\mathrm{a}}$ séries $^{9}$, PNLD/2004 e 2007)?

- Que letramentos se possibilita desenvolver com estas escolhas para a composição da coletânea?

A interpretaçáo dos resultados obtidos para responder às duas questôes levará em conta, na medida do possível, as questóes relativas aos multiletramentos, aos letramentos multissemióticos e aos letramentos críticos e protagonistas.

\section{As coletâneas de textos dos LDP - metodologia de análise}

A análise que aqui desenvolveremos será uma análise documental, de caráter quantitativo, de dois conjuntos de LDP de $1^{\text {a a }} 4^{a}$ série do Ensino Fundamental, avaliados nos PNLD/2004 e $2007^{10}$.

As amostras dos dois PNLD são compostas pelo mesmo número de coleçóes e de volumes, tendo sido avaliadas, em cada uma das duas ediçóes do Programa, 43 coleçóes de LDP, contando, cada uma, com 4 volumes seriados (172 volumes) na versão Livro do Aluno (LA) e Manual do Professor (MP), perfazendo, no total, 344 volumes para cada ediçáo do Programa. Os livros avaliados no PNLD/2004 estiveram nas redes públicas de 2004 ao final de 2006 e os do PNLD/2007 foram utilizados de 2007 até o final de 2009.

Para a coleta dos dados, utilizamos as Fichas de Avaliação das Coleçóes de LDP do PNLD/2004 e do PNLD/2007 $7^{11}$. Nessas fichas, ao final, constam listagens feitas pelos avaliadores do conjunto dos textos (verbais e não verbais) das coletâneas de cada volume, com informaçóes, quando for o caso, sobre o título do texto, sua autoria e/ou seu veículo de circulaçáo, o gênero a que pertence e a página do volume do LDP em que se encontra. 
Com base nessas listagens, a equipe paulista do Grupo de Pesquisa "Livro Didático de Língua Portuguesa - Produção, Perfil e Circulação (LDP_Proferfil)” do Diretório de Pesquisa do Conselho Nacional de Desenvolvimento Científico e Tecnológico (CNPq), sob nossa coordenação, elaborou Bases de Dados dos Textos e Coletâneas ${ }^{12}$, onde constam esses dados, revistos pelos pesquisadores e acrescidos das esferas de circulação dos gêneros e textos elencados. Essas Bases permitem análises, por diversos critérios, das coletâneas dos volumes, das séries, das coleçóes e do total da amostra avaliada.

A quantificação, por gêneros e esferas, foi elaborada a partir dessas Bases de Dados, que permitiriam ainda cálculos sobre autoria e veículos de circulação. Para melhor compreensão das Bases e da quantificação realizada, cabem ainda alguns comentários.

Em primeiro lugar, é preciso esclarecer que o título, o veículo e o gênero dos textos listados foram, muitas vezes, informaçóes da maior relevância para as decisões dos pesquisadores sobre as esferas de circulação. Por exemplo, a indicação do avaliador de um texto intitulado "Democracia", publicado na Revista Zá e qualificado como Artigo, levou o pesquisador a categorizá-lo como da esfera jornalística.

Em segundo lugar, cabe notar que esta decisão não foi nunca isenta de dúvidas ${ }^{13}$, embora tenhamos evitado oscilaçóes na Base e entre Bases. Muitas delas eram determinadas pelo fato de que a esfera de circulação do texto nem sempre coincide com sua esfera de produção. É o caso, por exemplo, das HQ e tirinhas, que são produzidas por cartunistas e quadrinistas ligados à esfera de produção das Artes Gráficas - tendo inclusive suas associações, concursos e exposiçóes -, mas que são veiculados pela esfera jornalística, em jornais e revistas de entretenimento, e que foram considerados como gêneros pertencentes à esfera do entretenimento. A cada vez que tivemos que tomar decisões deste tipo, entre esfera de produção e de circulação, optamos pela segunda, por julgarmos que a esfera de circulação abrange mais facetas das práticas letradas ligadas à recepção dos textos.

Por fim, como veremos adiante, nem sempre foi possível compatibilizar gêneros e esferas com as esferas de letramento indicadas em Ribeiro e utilizadas no INAF. Por exemplo, na esfera do lazer podem estar elencados tanto textos de entretenimento como das artes plásticas, gráficas, literária, musical etc., assim como na esfera doméstica podem ocorrer usos de textos 
cotidianos, jornalísticos, publicitários etc. Assim, acabamos por reformular esse conceito superordenado, optando por três "âmbitos de letramento": das artes, da divulgação científica e da cidadania.

Assim, o Quadro 1 exibe as categorias de análise:

\begin{tabular}{|c|c|c|}
\hline Âmbitos & $\begin{array}{l}\text { Esferas de } \\
\text { circulação/ } \\
\text { produção dos } \\
\text { textos } \\
\end{array}$ & Gêneros \\
\hline \multirow{7}{*}{ das Artes } & Artes da imagem & $\begin{array}{l}\text { Cena de filme, de desenho animado, } \\
\text { storyboard, fotografia, fotolegenda... }\end{array}$ \\
\hline & Artes gráficas & $\begin{array}{l}\text { Ilustração, reprodução de xilo ou } \\
\text { litogravura... }\end{array}$ \\
\hline & Artes plásticas & $\begin{array}{l}\text { Reprodução de pinturas, esculturas, } \\
\text { grafites... }\end{array}$ \\
\hline & Artes musicais & $\begin{array}{l}\text { Letra de canção, de samba-enredo, } \\
\text { RAP, reprodução de partituras e } \\
\text { cifras... }\end{array}$ \\
\hline & Literária & $\begin{array}{l}\text { Autobiografia, conto, crônica, } \\
\text { poemas, novelas, peças teatrais, } \\
\text { limeriks... }\end{array}$ \\
\hline & $\begin{array}{l}\text { Literatura } \\
\text { infantojuvenil }{ }^{14}\end{array}$ & $\begin{array}{l}\text { Conto de fadas, populares, fábulas, } \\
\text { narrativas de aventura, de enigma, de } \\
\text { ficção científica... }\end{array}$ \\
\hline & Tradição oral & $\begin{array}{l}\text { Adivinha, cordel, lenda, letra de } \\
\text { cantiga, parlenda, piada, trava- } \\
\text {-língua... }\end{array}$ \\
\hline \multirow{2}{*}{$\begin{array}{l}\text { da Divulgação } \\
\text { Científica }\end{array}$} & $\begin{array}{l}\text { Divulgação } \\
\text { Científica }\end{array}$ & $\begin{array}{l}\text { Artigo, verbete, citação, curiosidades, } \\
\text { bula, biografia, infográfico, mapa, } \\
\text { tabela, relato histórico... }\end{array}$ \\
\hline & Escolar & $\begin{array}{l}\text { Descrição, diálogo, enunciado de } \\
\text { problema, instrução, lembrete, lista, } \\
\text { narrativa, opinião, redação, resumo... }\end{array}$ \\
\hline
\end{tabular}




\begin{tabular}{|l|l|l|}
\hline \multirow{5}{*}{ da Cidadania } & Cotidiana & $\begin{array}{l}\text { Agenda, bilhete, aviso, calendário, } \\
\text { cardápio, carta, conversa, convite, } \\
\text { diário íntimo, receita, telegrama... }\end{array}$ \\
\cline { 2 - 3 } & Burocrática & $\begin{array}{l}\text { Carteira de identidade, certidão de } \\
\text { nascimento, formulário, logotipo... }\end{array}$ \\
\cline { 2 - 3 } & Digital ${ }^{15}$ & Chat, email, homepage, spot... \\
\cline { 2 - 3 } & Entretenimento & $\begin{array}{l}\text { Caça-palavra, desafio, palavra } \\
\text { cruzada, HQ, Tirinha, Cartum... }\end{array}$ \\
\cline { 2 - 3 } da Cidadania & $\begin{array}{l}1^{\text {a }} \text { página, artigo, artigo de opinião, } \\
\text { charge, entrevista, notícia, reporta- } \\
\text { gem... }\end{array}$ \\
\hline & Jornalística & Artigo de lei \\
\cline { 2 - 3 } & Jurídica & Carta comercial, cheque, nota fiscal... \\
\cline { 2 - 3 } & Pegócios & Declaração, hino, manifesto... \\
\cline { 2 - 3 } & Publicitária & $\begin{array}{l}\text { Anúncio, classificado, campanha, } \\
\text { folder, logomarca, rótulo... }\end{array}$ \\
\cline { 2 - 3 } & Religiosa & Prece, profecia... \\
\hline
\end{tabular}

Quadro 1 - Âmbitos de letramento, esferas e gêneros dos textos das coletâneas

\section{As coletâneas dos LDP de $1^{\underline{a}}$ a $4^{\underline{a}}$ série - Alguns resultados}

Em primeiríssimo lugar, cabe notar que, permanecendo as duas amostras com o mesmo número de coleções e volumes, houve um razoável aumento do número de textos elencados pelos avaliadores entre uma e outra edição do programa. No PNLD/2004, os LDP apresentaram, intercalados no discurso autoral, um conjunto de 10.808 textos em gêneros variados, com uma média de 63 textos por volume avaliado. No PNLD/2007, este número cresce para 12.360 - um aumento, portanto, de 1.552 textos (12,5\%) -, verificando-se uma média de 72 textos por volume, 9 a mais, portanto. Este aumento do número de textos pode ser devido aos efeitos da própria avaliação, às novas obras inscritas ou às obras reformuladas, mas também a uma maior acuidade dos avaliadores ao elaborarem a listagem, uma vez que este levantamento estava sendo feito pela segunda vez e os avaliadores, portanto, encontravam-se já mais treinados para a tarefa.

Desses textos, a maior parte pertence ao âmbito das artes, seguido do de divulgação científica e da cidadania. Vejamos o Gráfico 1: 


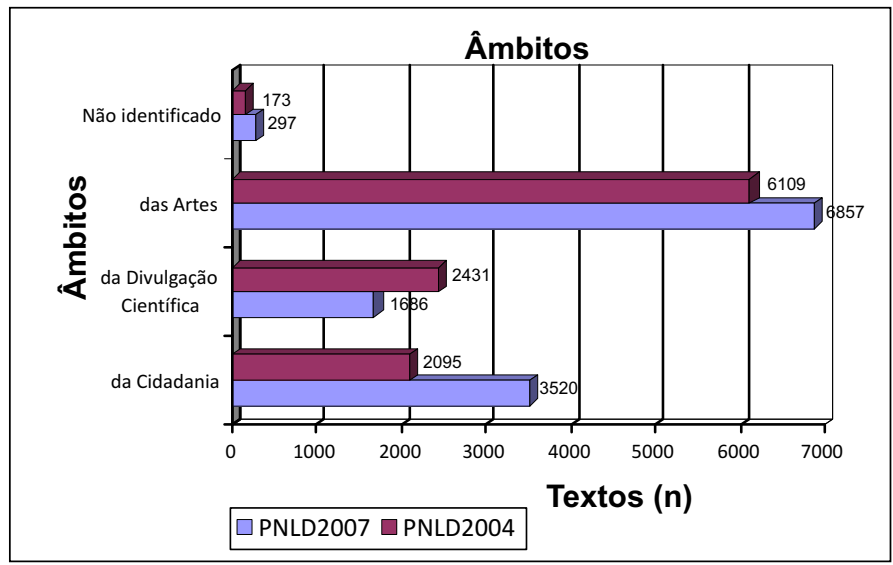

Gráfico 1: Âmbitos de distribuição dos textos das coletâneas

Como se vê, entre o PNLD/ 2004 e o PNLD/2007, há um crescimento do número de textos que circulam nas esferas artísticas. No entanto, quanto aos dois outros âmbitos, há uma inversão de privilégio entre as duas ediçóes do PNLD: no PNLD/2004, ficavam em segundo lugar de incidência os textos de divulgação científica e didáticos; no PNLD/2007, há um grande crescimento do número de textos do âmbito da cidadania, em suas diferentes esferas, passando este âmbito ao segundo lugar em incidência. Os dados são exibidos nos Gráficos 2 e 3.

Quais serão as esferas de circulação dos textos privilegiadas em cada um desses âmbitos de letramento? No caso do âmbito das artes, como é de se esperar, os textos literários são maioria, especialmente se considerarmos também como literários e não como paraescolares os textos da literatura infantojuvenil. 

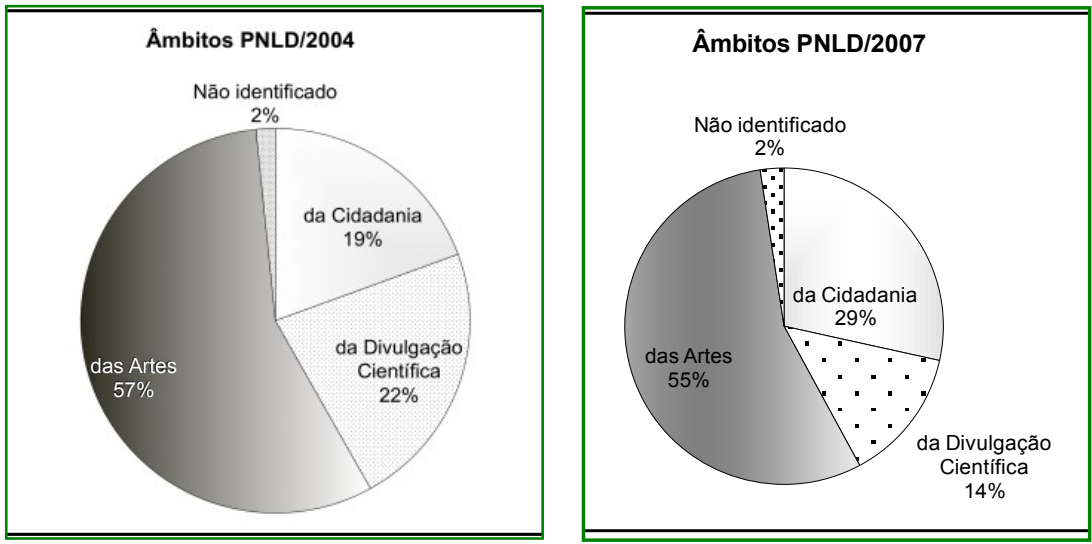

Gráficos 2 e 3: Âmbitos de distribuição dos textos das coletâneas nos PNLD/2004 e 2007.

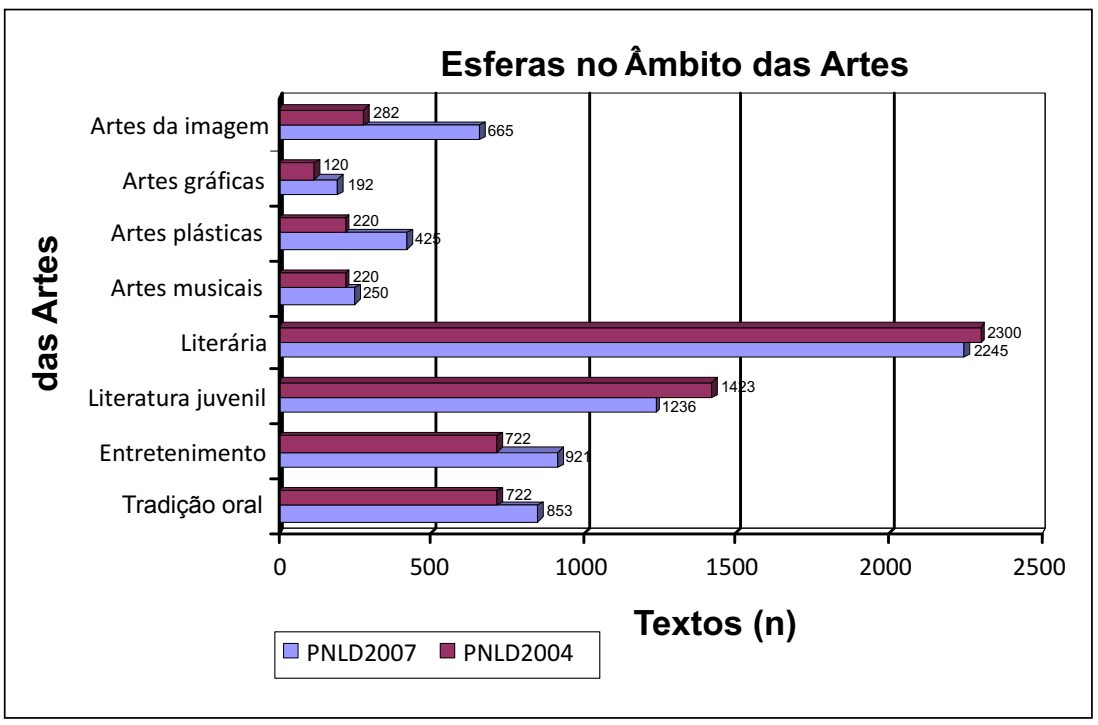

Gráfico 4: Distribuição dos textos por esferas no âmbito das artes.

Ficam em segundo e terceiro lugares as esferas do entretenimento e da tradição oral e, com diferenças entre uma e outra edição do Programa, 
aparecem nos últimos lugares de incidência os textos multissemióticos ou aqueles que se materializam em outras linguagens que não a verbal escrita (artes da imagem, artes gráficas, plásticas, musicais). Os Gráficos 5 e 6, a seguir, exibem os percentuais nos dois PNLD.

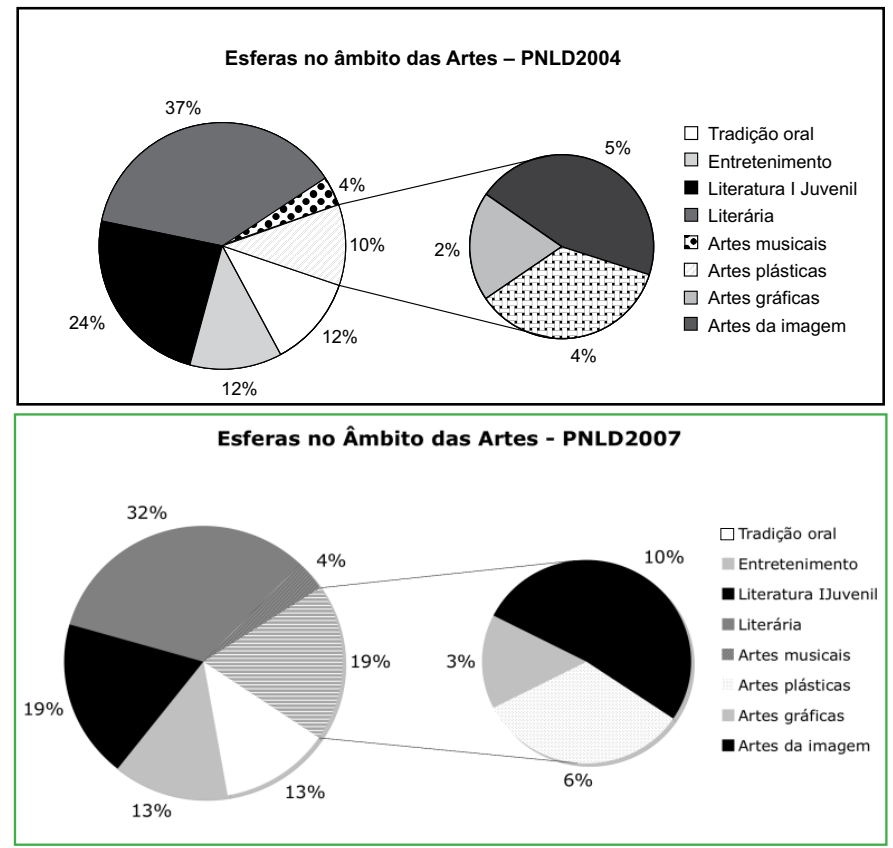

Gráficos 5 e 6: Distribuição dos textos por esferas no âmbito das artes nos PNLD/2004 e 2007.

Como vemos, entre uma e outra edição do Programa, diminui um pouco $(10 \%)$ a incidência de textos literários, se somadas a literatura e a literatura infantojuvenil. Entretanto, esses sempre constituem pelo menos a metade dos textos da esfera das artes. No PNLD/2004, ficavam em segundo lugar, de maneira equilibrada, as esferas da tradição oral, do entretenimento e das artes da imagem (da imagem, plásticas e gráficas). Essas últimas crescem em 9\% no PNLD/2007, assumindo o segundo lugar de incidência, com $19 \%$ dos textos, e deslocando para terceiro lugar de incidência (13\%) as esferas da tradição oral e do entretenimento. Em último lugar, comparecem, nos dois casos, as artes musicais (4\%). Esses dados apontam novamente para 
um crescimento do número de textos multimodais e em outras linguagens nas coletâneas, favorecendo, em princípio, os letramentos multissemióticos.

Vimos que o âmbito da divulgação da ciência cede lugar ao da cidadania, entre uma e outra edição do PNLD. No caso do âmbito da divulgação científica, há uma radical diminuição dos textos da esfera de divulgação científica propriamente dita, em favor, seja do aumento do número de textos do âmbito da cidadania, seja daqueles mais propriamente escolares. Vejamos os dados nos Gráficos 7 a 9.

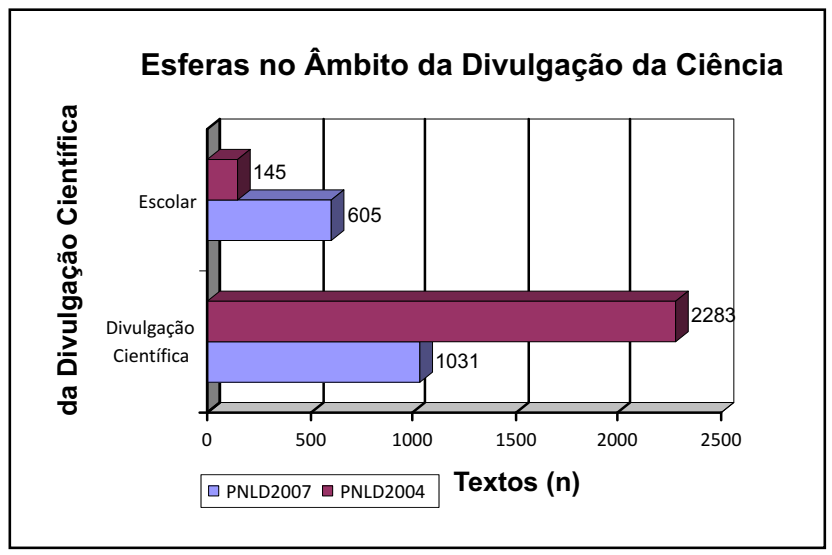

Gráfico 7: Distribuição dos textos por esferas no âmbito da divulgação científica

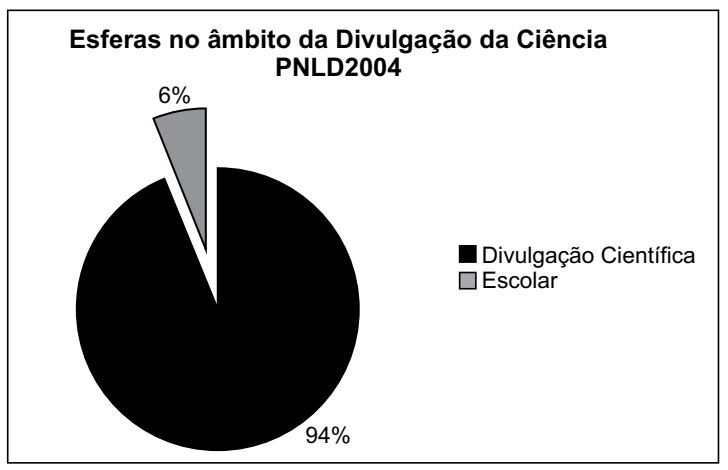

Gráfico 8: Distribuição dos textos por esferas no âmbito da divulgação científica no PNLD/2004 


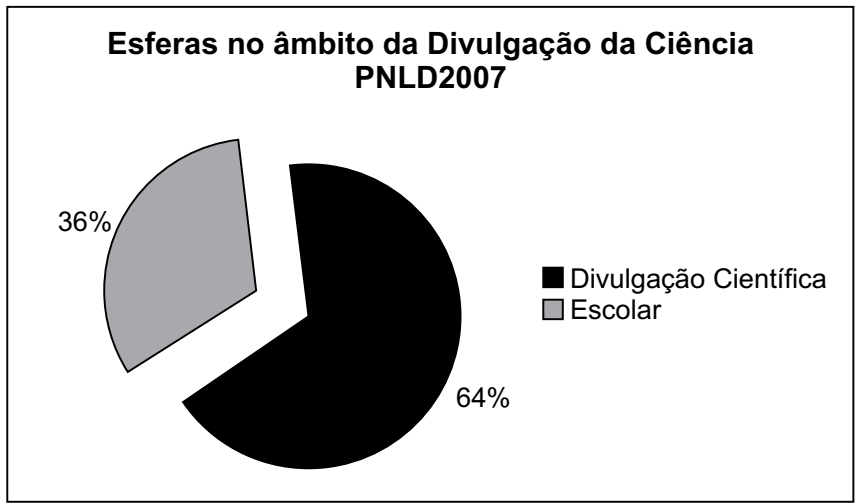

Gráfico 9: Distribuição dos textos por esferas no âmbito da divulgação científica no PNLD/2007

Já os textos do âmbito dos letramentos para a cidadania, cujo número cresce consideravelmente do PNLD/2004 para o PNLD/2007, espalham-se por uma diversidade de esferas de circulação, mas com predomínio quase absoluto das esferas jornalística, publicitária e cotidiana.

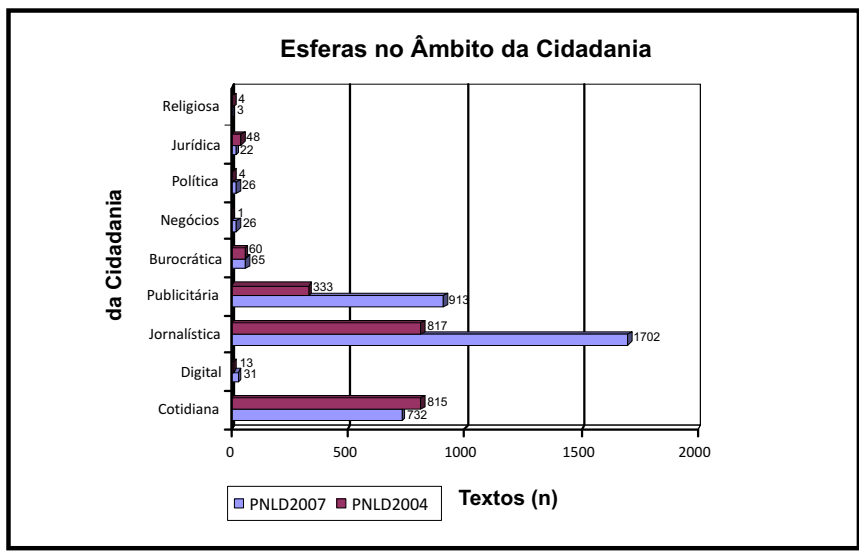

Gráfico 10: Distribuição dos textos por esferas no âmbito da cidadania

Como vemos, entre o PNLD/2004 e o PNLD/2007, há um crescimento do número de textos jornalísticos e publicitários e uma diminuição dos textos de circulação cotidiana, mas os textos dessas três esferas perfazem a grande maioria dos textos de letramentos do âmbito 
da cidadania. As outras esferas (digital, burocrática, jurídica, política, dos negócios e religiosa) apresentam de 65 textos a 1 único texto. Pode-se falar numa perspectiva característica da virada comunicativa ou pragmática ${ }^{16}$ na abordagem dos textos que funcionam nas esferas do âmbito da cidadania. Os Gráficos 11 e 12 exibem os percentuais para cada edição do PNLD.

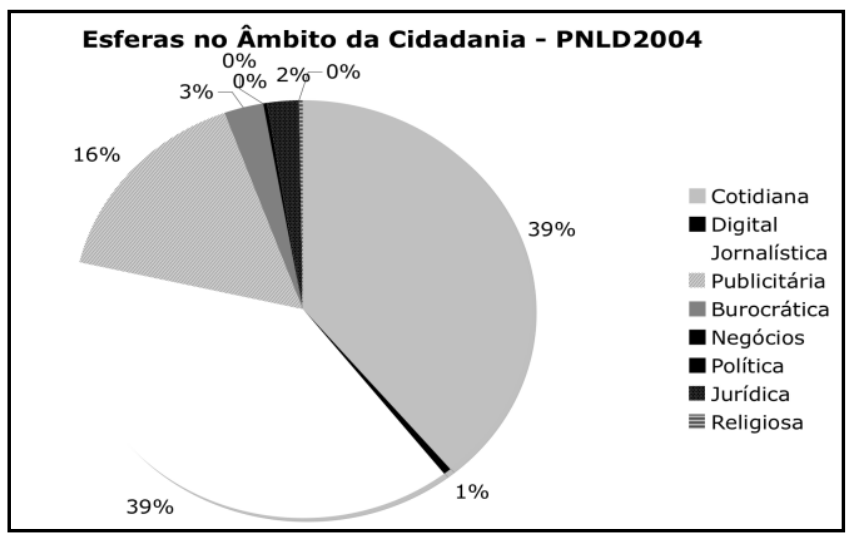

Gráfico 11: Distribuição dos textos por esferas no âmbito da cidadania no $\mathrm{PNLD} / 2004$

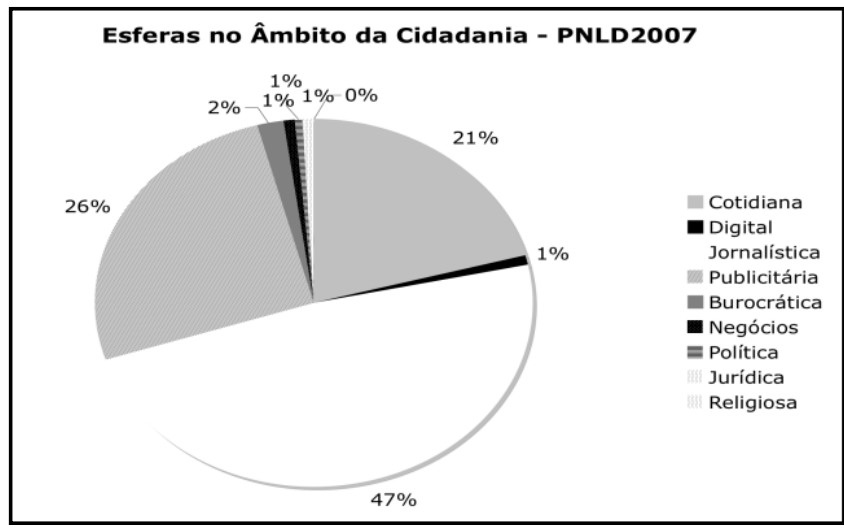

Gráfico 12: Distribuição dos textos por esferas no âmbito da cidadania no PNLD/2007

Cabem agora alguns comentários sobre os gêneros dessas esferas principais privilegiados pelos LDP. No caso da esfera literária - que 
constitui 35\% dos textos das coletâneas dos LDP do PNLD/2004 e 28\% do PNLD/2007 -, são muito frequentes os poemas ${ }^{17}$, vindo em segundo lugar, com incidência bem menor, os contos e as crônicas. Todos os outros gêneros literários (autobiografia, novelas, peças teatrais, limeriks, hai-kais etc.) margeiam em frequência os contos e crônicas. No caso da literatura infantojuvenil, são muito frequentes as narrativas de aventura, secundadas, com grande diferença também, pelas fábulas. Outros gêneros (contos de fadas, populares, narrativas de enigma, de ficção científica etc.) são de incidência muito pequena. Vejamos os Gráficos 13 e 14 .

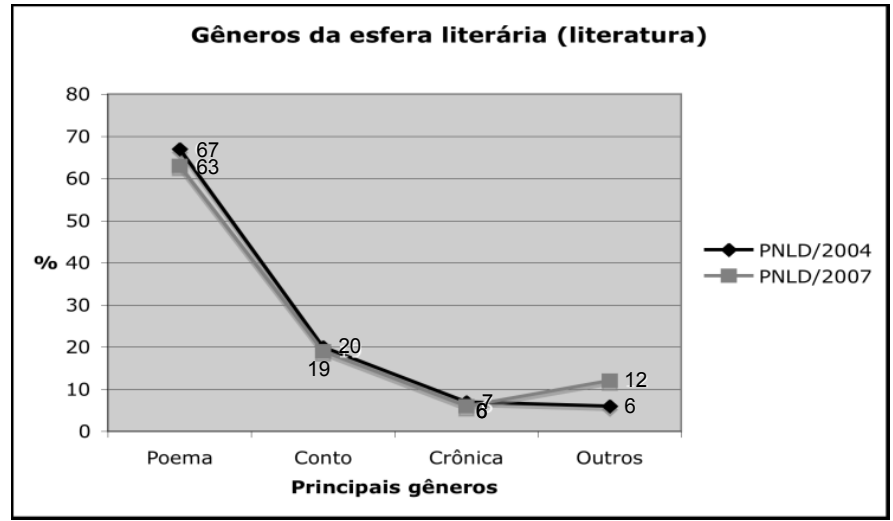

Gráfico 13: Frequência dos gêneros da esfera literária nos PNLD/2004 e PNLD/2007

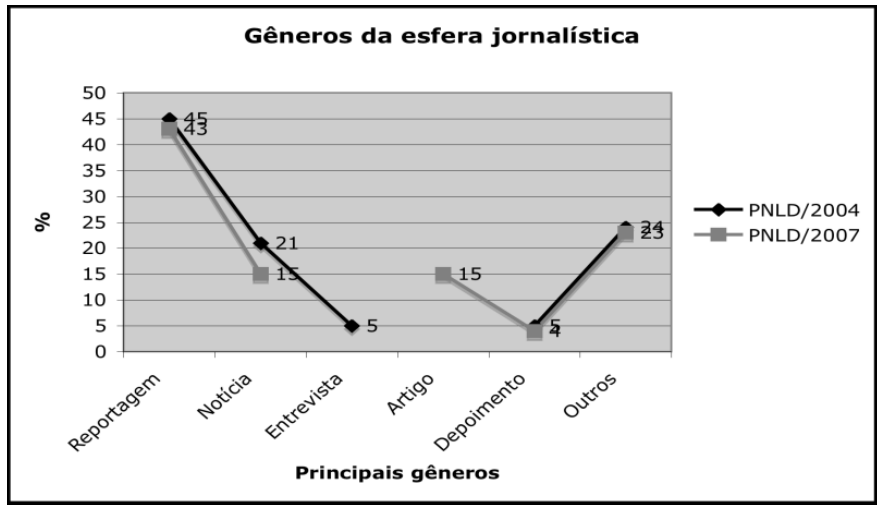

Gráfico 14: Frequência dos gêneros da esfera da literatura infantojuvenil nos PNLD/2004 e PNLD/2007 
No âmbito dos letramentos para a cidadania - 19\% dos textos do PNLD/2004 e 28\% dos do PNLD/2007 -, também os gêneros jornalísticos se apresentam de maneira bastante semelhante nos dois PNLD. No PNLD/2004, há somente textos de jornalismo de informação, com privilégio das reportagens, notícias e entrevistas. No PNLD/2007, há alguma presença também do jornalismo de opiniāo, com pequena incidência de artigos. Todos os outros gêneros jornalísticos (1 ${ }^{a}$ página, charge, por exemplo) perfazem cerca de 25\% das coletâneas nos dois PNLD.

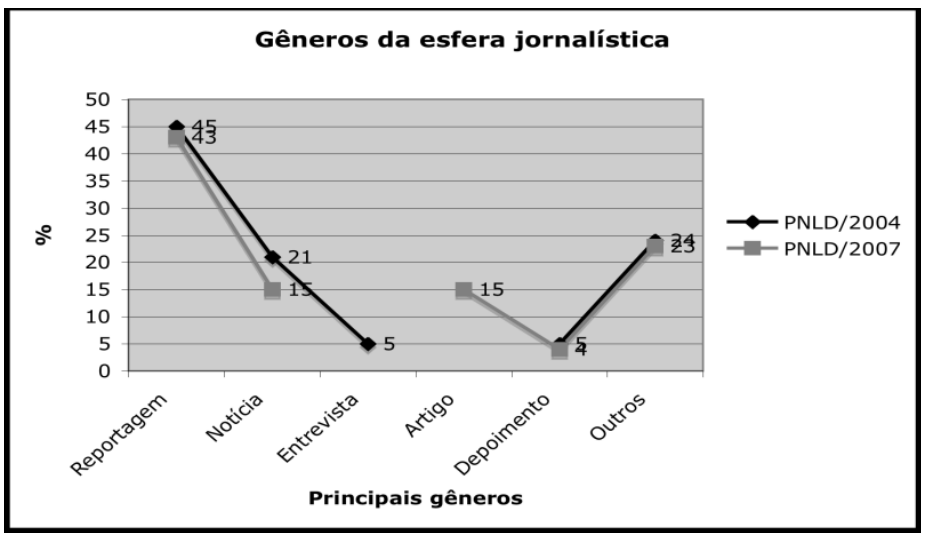

Gráfico 15: Frequência dos gêneros da esfera jornalística nos PNLD/2004 e PNLD/2007

Já os gêneros das esferas publicitária e cotidiana são diferenciados nas duas edições do Programa. Da esfera publicitária, no PNLD/2004, são frequentes os anúncios e, no PNLD/2007, as capas (de DVD, vídeo, CD, livros) e os anúncios. Outros gêneros (classificados, campanha publicitária, folder, logomarca, rótulo etc.) têm menos incidência.

Os gêneros da esfera cotidiana são bastante diversificados $(22 \%$ de outros no PNLD/2004 e 43\%, no PNLD/2007: agenda, bilhete, aviso, calendário, cardápio, carta, conversa, convite etc.), com predomínio dos textos injuntivos (instruçóes, receitas, regras de jogo). A tendência, no PNLD/2007, foi de aumento da diversidade de textos e de gêneros cotidianos. 


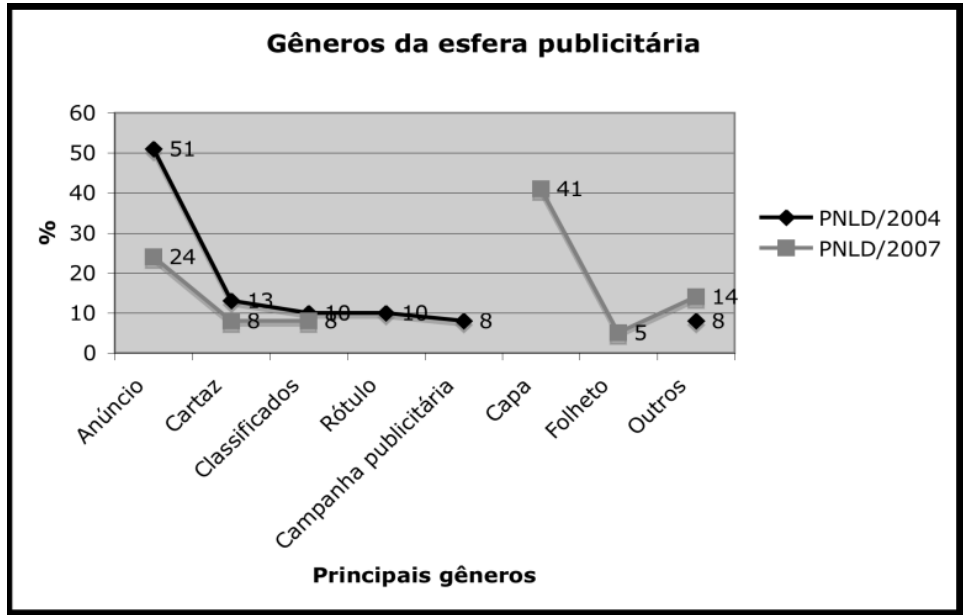

Gráfico 16: Frequência dos gêneros da esfera publicitária nos PNLD/2004 e $\mathrm{PNLD} / 2007$

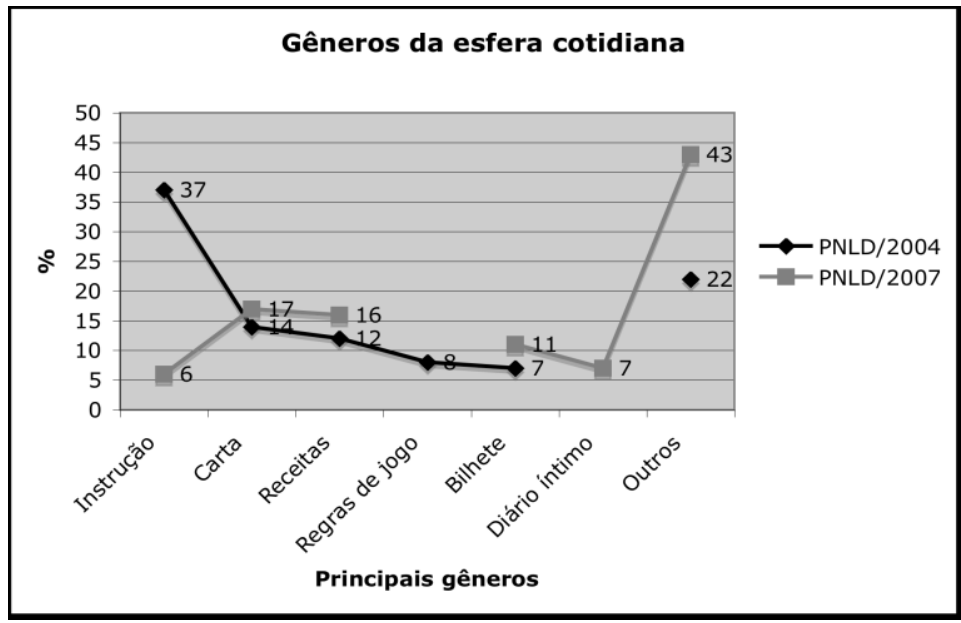

Gráfico 17: Frequência dos gêneros da esfera cotidiana nos PNLD/2004 e PNLD/2007

No que diz respeito ao âmbito dos letramentos no campo da divulgação científica (esfera escolar e jornalismo de divulgação científica $22 \%$ dos textos no PNLD/2004 e 14\% dos do PNLD/2007), predominam os textos expositivos propriamente ditos (escolares, no PNLD/2004) e os 
verbetes (de dicionário, de enciclopédia) no PNLD/2007. De resto, os outros gêneros (artigo, citação, curiosidades, bula, biografia, infográfico, mapa, tabela, relato histórico etc.) têm uma incidência menor nos dois PNLD.

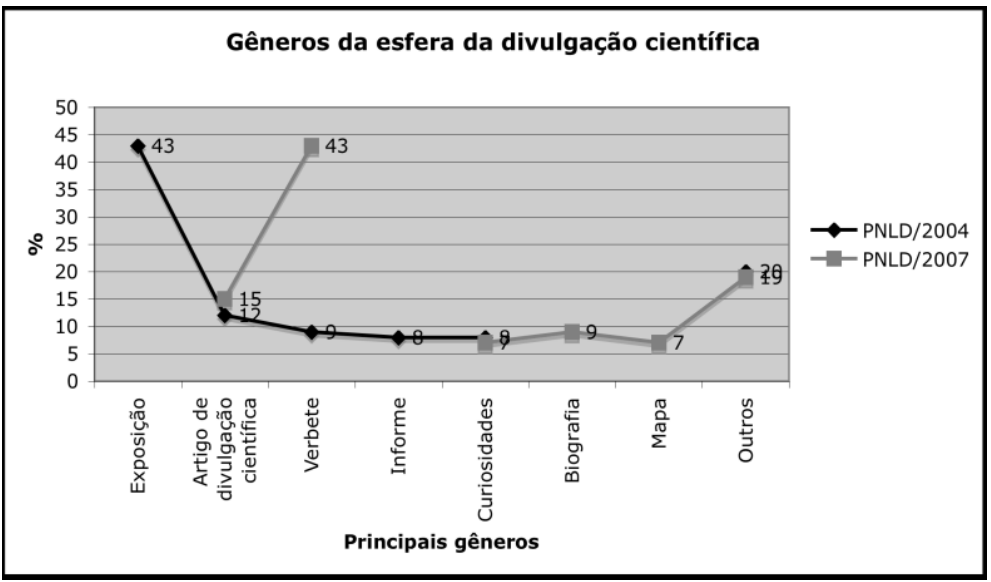

Gráfico 18: Frequência dos gêneros da esfera da divulgaçáo científica nos PNLD/2004 e PNLD/2007

\section{Breve síntese dos resultados e conclusão: possibilidades de letramentos}

Vimos que os textos relativos aos letramentos no âmbito das artes são privilegiados (57\%), em especial, os textos literários e da literatura infantojuvenil, que perfazem 35\% dos textos no PNLD/2004 e 28\% no PNLD/2007.

Vimos também que os textos relativos aos letramentos do âmbito da cidadania ampliam seu número, passando a tomar espaço dos gêneros escolares/de divulgação científica $(22 \%>14 \%)$, com destaque para os gêneros jornalísticos de informação $(7 \%>14 \%)$ e publicitários $(3 \%>7 \%)$, que ganham espaço em detrimento dos gêneros cotidianos $(7 \%>6 \%)$. Não há, entretanto, muito espaço para os textos do jornalismo de opiniáo ou para aqueles da esfera digital $(0,13 \%>0,25 \%)$. Essas mudanças se caracterizam, aparentemente, como uma espécie de "virada pragmática" das coletâneas dos LDP, a partir do aumento de incidência dos textos 
jornalísticos e publicitários sobretudo, com 40 anos de atraso em relação à virada comunicativa propriamente dita.

Por fim, pudemos também notar que a dita "diversidade de gêneros/ tipos” constatada pelos avaliadores do PNLD é bastante relativa, pois há alta concentração em dois ou três gêneros de cada esfera, e a percepção de "diversidade" parece ser induzida pela presença de alguns poucos exemplares de textos em uma multiplicidade de gêneros, ao longo das quatro séries do Ensino Fundamental ${ }^{18}$. A esfera literária e da literatura infantojuvenil parece ser a mais conservadora a esse respeito, mantendo sua fixação já tradicional em poemas, contos e narrativas de aventura.

Cabe agora retomar a discussão sobre quais letramentos essas coletâneas possibilitam desenvolver. No que se refere aos letramentos múltiplos, parece estar havendo uma passagem do letramento escolar tradicional (poética, retórica) para uma multiplicidade maior de letramentos, ainda tímida quanto a linguagens e mídias e pautada nas esferas da virada pragmática (jornalismo, publicidade). Esse movimento se configura como um avanço ainda bastante tímido na direção dos multiletramentos.

Quanto aos letramentos multissemióticos e multimidiáticos, esses são pouquíssimo contemplados. Vimos que os textos da esfera digital são praticamente desprezados e não tivemos espaço para comentar em mais detalhes os textos multimodais ou multissemióticos, dada justamente sua pequena frequência. Vimos que, nos PNLD/2004 e 2007, os textos ligados às artes musicais perfazem $4 \%$; às artes da imagem (propriamente dita, artes plásticas e gráficas) $10 \%>19 \%$ e aqueles da esfera do entretenimento (caça-palavra, desafio, palavra cruzada, HQ, tirinha, cartum etc.), quase todos multimodais, $12 \%>13 \%$. Aparecem também uns poucos gráficos, infográficos, mapas e tabelas na esfera da divulgação científica.

Considerando-se que os textos da esfera das artes musicais são tratados de maneira unimodal (como letras de cançóes, muitas vezes designadas como "poemas" pela autoria), e que os das artes da imagem são, em geral, unimodais (reprodução de pintura, gravura, escultura, fotos, ilustrações), reteremos como textos efetivamente apresentados como multimodais ou multissemióticos aqueles poucos da esfera de divulgação científica e os $12 \%$ a 13\% de textos da esfera do entretenimento. Sabemos também, entretanto, que os textos desses gêneros (tira, cartum, HQ, por exemplo), assim como os poemas e anúncios publicitários, não são muitas vezes tomados nos 
LDP como textos de leitura, mas como pretexto para ensino ou análise gramatical. Logo, não são de estranhar os pobres resultados de nossos alunos nos exames e avaliaçóes que propóem leitura de textos multissemióticos, quando nem mesmo as coletâneas dos materiais didáticos disponíveis dão espaço a esses textos.

$\mathrm{O}$ acesso a dados a respeito dos letramentos críticos e protagonistas é muito restrito no tipo de estudo que levamos a efeito aqui. No entanto, temos indícios para hipotetizar que também não são foco de preocupação central. Um deles é a presença muito restrita, nas coletâneas, de textos em gêneros argumentativos e do jornalismo de opiniáo.

Finalmente, os letramentos na perspectiva multicultural, que requerem o contato com textos das culturas locais e juvenis, também não parecem ser um ponto de atenção. Embora haja um percentual de textos da tradição oral - sobretudo textos infantis como adivinhas, letras de cantiga, parlendas, trava-línguas, mas também textos de cordel e lendas -, que perfazem 7\% dos textos das coletâneas nos dois PNLD, o predomínio absoluto é dos textos escritos em língua padrão pertencentes a gêneros valorizados da cultura letrada e, quando é o caso (poemas e contos, por exemplo), ao cânone.

O que concluímos desta análise é que, pelo menos no que tange aos LDP, a escola ainda está longe de incorporar os letramentos requeridos na contemporaneidade e mais longe ainda de realizar os ideais anunciados por Oswald de Andrade no Manifesto Pau Brasil, de 1924, de fazê-lo sem perder de vista o Museu Nacional ou o Pau Brasil, isto é, integrando e colocando em diálogo, culturas locais e valorizadas.

\section{Notas}

1 Agradecemos ao CNPq o apoio a esta pesquisa, configurado no Grupo de Pesquisa certificado pela Unicamp no Diretório CNPq, intitulado Livro Didático de Língua Portuguesa: Produção, Perfil e Circulação, acrônimo LDP-Properfil.

2 Letramentos, aqui, são definidos como uma grande variedade de práticas de linguagem que envolvem, de uma ou de outra maneira, textos escritos.

3 Tradução nossa. This entails the recognition of multiple literacies, varying according to time and space, but also contested in relations of power. NLS, then, takes nothing for granted with respect to literacy and the social practices 
with which it becomes associated, problematizing what counts as literacy at any time and place and asking "whose literacies" are dominant and whose are marginalized or resistant. (STREET, 2003, p. 77).

4 Santos (2005, p. 74) aponta para a globalização ou coligaçâo contrahegemônica, que não se baseia no incremento e na proteção do local enraizado - embora não negue seu valor estratégico, designando-o como localização contra-hegemônica -, mas no que ele chama de as iniciativas, organizaçóes e movimentos integrantes do cosmopolitismo e do patrimônio comum da humanidade, com vocação transnacional, mas ancoradas em lutas locais concretas, dentre elas, a escola. [...] O global acontece localmente. É preciso fazer com que o local contra-hegemônico também aconteça globalmente.

5 Segundo Ribeiro (2003, p. 7-9), o INAF, realizado pelo Instituto Paulo Montenegro/IBOPE e pela ONG "Ação Educativa”, é uma "pesquisa anual" para fazer um "levantamento nacional sobre o alfabetismo funcional de jovens e adultos", fornecendo "à sociedade brasileira um conjunto de informaçóes sobre habilidades e práticas relacionadas à leitura, escrita e matemática da população brasileira”.

6 69\% dos entrevistados nunca foram a uma biblioteca.

7 Por exemplo, o Programa do Ministério da Educação/ Fundo Nacional de Desenvolvimento da Educação (MEC/FNDE) denominado "A literatura em minha casa”. Segundo o site da ABRELIVROS (Associação Brasileira dos Editores de Livros), "uma das estrelas do Programa Nacional Biblioteca da Escola (PNBE), do (FNDE/MEC), o Literatura em Minha Casa distribui, desde abril de 2002, uma coleção de livros para estudantes da 4 a série do ensino fundamental com a finalidade de desenvolver o gosto pela leitura. A coleção, que se torna propriedade do aluno, é composta de cinco volumes, sendo uma obra da poesia ou antologia poética, um conto ou antologia de contos, uma novela e uma peça teatral, todos brasileiros, e um clássico da literatura universal traduzido ou adaptado. A cada ano, são distribuídas oito coleçôes diferentes, o que, além de atender os estudantes da $4^{a}$ série, permite a troca de livros entre eles. Todas as escolas públicas municipais e estaduais com turmas de $4^{\underline{a}}$ série recebem as coleçóes, o que possibilita que alunos de outras turmas tenham acesso às demais obras. No lançamento do Literatura em Minha Casa, em 2002, os alunos da 5ạ série também 
receberam as coleçôes. Nos anos seguintes, a distribuição foi dirigida à 4a série." (http://www.abrelivros.org.br/abrelivros/texto.asp?id=613, acesso em 07/09/2007).

8 Por razões dos limites deste texto, não vamos realizar a ampla discussão do(s) conceito(s) de cultura (valorizada e não valorizada, popular e autorizada, particular e universal, popular e de massa, indústria cultural, local e global) que seria exigida por esta distinção. Contamos com a boa vontade do leitor ao trabalhar com a distinção colocada de maneira difusa.

9 Escolhemos este segmento de ensino devido ao foco geral desta coletânea de artigos.

10 Segundo Batista (2003, p. 25-26), “o Programa Nacional do Livro Didático (PNLD) é uma iniciativa do Ministério da Educação (MEC). Seus objetivos básicos são a aquisição e a distribuição, universal e gratuita, de livros didáticos para os alunos das escolas públicas do ensino fundamental brasileiro. Realiza-se por meio do Fundo Nacional de Desenvolvimento da Educação (FNDE), autarquia federal vinculada ao MEC e responsável pela captação de recursos para o financiamento de programas voltados para o ensino fundamental. A fim de assegurar a qualidade dos livros a serem adquiridos, o Programa desenvolve, a partir de 1996, um processo de avaliação pedagógica das obras nele inscritas, coordenado pela Coordenação Geral de Avaliação de Materiais Didáticos e Pedagógicos (COMDIPE) da Secretaria da Educação Fundamental (SEF) do Ministério da Educação".

11 Agradecemos, em nome do Grupo LDP-Properfil, ao MEC e, em especial, à Prof ${ }^{-a}$ Nabiha Gebrim, coordenadora da COMDIPE/MEC até 2003, o livre acesso a esses documentos.

12 Disponíveis em <http://public.me.com/rrojo/>, na pasta LDP-Properfil.

13 Algumas entradas permaneceram mesmo na categoria "não identificadas".

14 Devido às discussóes sobre o caráter histórico paraescolar do desenvolvimento da edição do livro infantojuvenil no Brasil, consideramos em duas esferas separadas a literatura e a literatura infantojuvenil. 
15 Podemos questionar se o ambiente digital e a WEB constituem-se como uma esfera ou como uma sociedade virtual em que as esferas da sociedade atual são replicadas, como querem Castells e Lévy. Entretanto, mantivemos a categoria para podermos verificar com maior facilidade se os letramentos digitais são possibilitados pelas coletâneas.

16 Segundo Rojo (2008), na década de 70, “diante da reconfiguração dos objetivos da disciplina [de LP] e dos novos perfis de alunado e de professorado, diminui o beletrismo do ensino de português. Constituise um ensino mais preocupado com a realidade prática, que enfatiza sobretudo gêneros que circulam na comunicação de massa e nas mídias. Segundo Clare (2002: s/p), um ensino utilitário com a lingua voltada para a oralidade e, dessa forma, adequada à nova clientela que assola as escolas. É natural que novas teorias de referência - Teoria da Comunicação, Teoria da Recepção, Psicologia da Criatividade - comecem a circular nos documentos oficiais e em materiais didáticos. A língua valorizada como instrumento de comunicação, ensinavam-se elementos de comunicação e funçóes da linguagem". É a este movimento que estamos denominando aqui de "virada pragmática ou comunicativa".

17 Esses dados se confirmam no trabalho de Padilha (2005) sobre o tratamento dos textos literários no LDP.

18 Os dados do trabalho de Pedrosa (2006) constatam este mesmo efeito na avaliação das propostas de produção de textos dos LDP.

\section{REFERÊNCIAS}

ABREU, M. Os números da cultura. In: V. M. RIBEIRO (Org.). Letramento no Brasil. SP: Ação Educativa/Instituto Paulo Montenegro/ Global, 2003. p. 33-45.

BAKHTIN, M. M.;VOLOCHÍNOV, V. N. Marxismo e filosofia $d a$ linguagem. 2. ed. São Paulo: Hucitec, 1992.

BAKHTIN, M. M. Os gêneros do discurso. In: Estética da criação verbal. São Paulo: Martins Fontes, 2003. p. 277-326.

BARTON, D. Preface: literacy events and literacy practices. In:

BARTON, D.; HAMILTON, M.; IVANIC, R. Worlds of literacy.

Clevedon: Multilingual Matters Ltd, 1994. 
BARTON, D.; HAMILTON, M. Local literacies: reading and writing in one community. London: Routledge, 1998.

BATISTA, A. A. G. A avaliação dos livros didáticos: para entender o Programa Nacional do Livro Didático (PNLD). In: ROJO, R. H. R.; BATISTA, A. A. G. (Org.) Livro didático de Lingua Portuguesa, letramento e cultura da escrita. Campinas: Mercado de Letras, 2003. p. 25-68.

BEAUDOUIN, V. De la publication à la conversation: lecture et écriture électroniques. Réseaux, Paris, n. 119, p. 199-225, juin. 2002. Diponível em: <http://www.cairn.info/article.php?ID_REVUE=RES\&ID_ NUMPUBLIE=RES_116\&ID_ARTICLE=RES_116_0199>. Acesso em: 26 mar. 2007.

BUNZEN, C. S. Livro didático de Lingua Portuguesa: um gênero do discurso. Dissertação (Mestrado em Lingüística Aplicada) - Instituto de Estudos da Linguagem da Universidade Estadual de Campinas, Campinas, 2005.

BUNZEN, C. S.; ROJO, R. H. R. Livro didático de Língua Portuguesa como gênero do discurso: autoria e estilo. In: VAL, M. G. Costa; MARCUSCHI, B. (Org.). Livros didáticos de Lingua Portuguesa: letramento e cidadania. Belo Horizonte: Autêntica/CEALE, 2005. p. 73-118.

CERTEAU, M. de $A$ invenção do cotidiano 1: artes de fazer. 5. ed. Petrópolis: Vozes, 1994.

CHARTIER, R. A aventura do livro: do leitor ao navegador. São Paulo: EDUNESP, 1998.

CLARE, N. A. V. (2002). 50 anos de ensino de Língua Portuguesa (1950-2000). Anais do VI Congresso Nacional de Lingüistica e Filologia, Cadernos do CNLF, Série VI: Leitura e Ensino de Línguas, s/p. Disponível em http://www.filologia.org.br/vicnlf/anais/ caderno06-05.html, acessado $12 / 01 / 2005$.

GEE, J. P. Social linguistics and literacies: ideology in discourses. London: Taylor \& Francis, 1996.

GRILLO, S. V. C. Divulgação científica na esfera midiática. Revista Intercâmbio, São Paulo, v. 15, 2006. Disponível em: <www.pucsp.br/pos/ lael/intercambio/pdf/grillo.pdf>. Acesso em: 30 ago. 2007. 
HAMILTON, M. Sustainable literacies and the ecology of lifelong learning. In: HARRISON, R. R. F.; HANSON, A.; CLARKE, J. (Org.). Supporting lifelong learning: perspectives on learning. London: Routledge/ Open University Press, 2002. v. 1, p. 176-187.

HEATH, S. B. Ways with words: language, life and work in communities and classrooms. Cambridge: Cambridge University Press, 1983.

KLEIMAN, A. B. Modelos de letramento e as práticas de alfabetização na escola. In: KLEIMAN, A. B. (Org.). Os significados do letramento: uma nova perspectiva sobre a prática social da escrita. Campinas, SP: Mercado de Letras, 1995. p. 15-64.

Ação e mudança na sala de aula: uma pesquisa sobre letramento e interação. In: ROJO, R. H. R. (Org.). Alfabetização e letramento: perspectivas lingüísticas. Campinas, SP: Mercado de Letras, 1998.

MOITA-LOPES, L. P.; ROJO, R. H. R. Linguagens, códigos e suas tecnologias. In: BRASIL. Ministério da Educação.Secretaria de Educação Básica. Departamento de Políticas de Ensino Médio. Orientaçóes curriculares de ensino médio. Brasília, DF, 2004. p. 14-56.

PADILHA, S. J. O ensino-aprendizagem dos gêneros poéticos no ensino fundamental: uma abordagem enunciativo discursiva. Tese de Doutorado apresentada ao Programa de Pós-Graduação em Lingüística Aplicada e Estudos da Linguagem da Pontifícia Universidade Católica de São Paulo, São Paulo, 2005.

PEDROSA, M. C. N. S. As atividades de produção textual escrita em livros didáticos de Português: caminhos e descaminhos na formação de produtores de textos. Dissertação (Mestrado em Linguística Aplicada) - Programa de Pós-Graduação em Lingüística Aplicada e Estudos da Linguagem da Pontifícia Universidade Católica de São Paulo, São Paulo, 2006.

PRINSLOO, M.; M. BREIER (Org.). The social uses of literacy: theory and practice in contemporary South Africa. Philadelphia: John Benjamins, 1996.

RIBEIRO, V. M. Por mais e melhores leitores: uma introdução. In: RIBEIRO, V. M. (Org.). Letramento no Brasil. São Paulo: Ação Educativa/Instituto Paulo Montenegro/ Ed. Global, 2003. p. 9-29. 
ROJO, R. H. R. Gêneros de discurso/texto como objeto de ensino de línguas: um retorno ao trivium? In: SIGNORINI, I. (Org.). [Re]Discutir texto, gênero e discurso. Sáo Paulo: Parábola, 2008. p. 73-108.

SANTOS, B. de S. Os processos da globalização. In: (Org.). $A$ globalização e as Ciências Sociais. São Paulo: Cortez, 2005. p. 25-102. STREET, B. V. Literacy in theory and practice. Cambridge: Cambridge University Press, 1984.

. Social literacies: critical approaches to literacy in development, ethnography and education. London: Longman, 1995.

What's "new" in new literacy studies? critical approaches to literacy in theory and practice. Current Issues in Comparative Education, v. 5, n. 2. Columbia, 2003. p. 77-91. 


\section{School literacies: Collections of texts in Portuguese textbooks}

\begin{abstract}
This article discusses the typical literacies of contemporaneity, in order to,then, focus attention on school literacies, based on the profile of collections of texts from the textbook of the Portuguese Language (LDP - Livro Didático de Lingua Portuguesa) that circulated at public elementary schools in Brazil (1st to 4th grade), from 2004 to 2009. The analysis of these collections in terms of represented genres and their spheres of movement, discusses the possible school literacies from these texts. The results show that the LDP is still far from incorporating the required literacies in the contemporaneity.
\end{abstract}

Keywords: Textbooks. Literacy. Reading. Writing.

\section{Literacidades escolares: coletáneas de textos en los libros didácticos de Lengua portuguesa}

Resumen

El presente artículo discute, primeramente, la literacidad característica de la contemporaneidad, posteriormente, centraliza su foco en la literacidad escolar, con base en el perfil de los libros didácticos de Lengua Portuguesa (LDP) que circularon en las redes públicas brasileras de la Enseñanza Fundamental (de $1^{\underline{a}}$ a $4^{\underline{a}}$ serie), de 2004 a 2009. El análisis de estos textos, en el sentido de géneros representados y de sus esferas de circulación, discute las literacidades escolares posibles a partir de esos textos. Los resultados muestran que los libros didácticos de lengua portuguesa están muy lejos de incorporar la literacidad requerida en la contemporaneidad.

Palabras clave: Libros didácticos. Alfabetización. Lectura. Escrita.

\section{Roxane Helena Rodrigues Rojo}

R. Sérgio Buarque de Holanda, 571, Baráo Geraldo.

CEP 13084-971, Campinas, SP

E-mail:rrojo@mac.com

Recebido em: $1 / 7 / 2010$ Aprovado em: 25/10/2010 